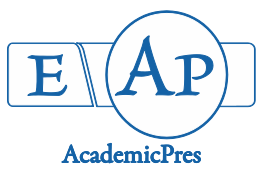

Njoku KL et al. (2020)

Notulae Scientia Biologicae 12(2):420-432

DOI:10.15835/nsb12210523

Research Article

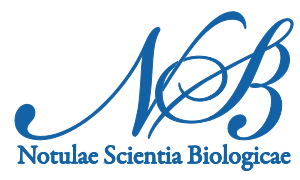

\title{
Growth and ability of Senna alata in phytoremediation of soil contaminated with heavy metals
}

\author{
Kelechi L. NJOKU*, Omolola E. OJO, Anuoluwapo O. JOLAOSO \\ University of Lagos, Environmental Biology Research Unit, Cell Biology and Genetics Department, P.O. Box 132, Akoka, Lagos, \\ Nigeria;knjoku@unilag.edu.ng(*'correspondingauthor);oeojo@unilag.edu.ng; anujolaoso@gmail.com
}

\begin{abstract}
The performance and impact of Senna alata on experimental heavy metal contaminated soil were investigated in this study. Soils in different pots were contaminated with different levels of lead, nickel, chromium and cadmium based on WHO limits for heavy metals. Seeds of $S$. alata were planted in the contaminated soils. The plant growth was studied for 60 days. Some soil parameters and heavy metal contents of the soil were evaluated at the beginning and at the end of the study. The leaf area, the plant height and the number of actively growing stems decreased with increase in the amount of each metal added to the soil. At 60 days, there was significant reduction $(\mathrm{p}<0.05)$ of the heavy metals due to the growth of $S$. alata compared to the soil without the plant. There was reduction in the total organic matter content and the $\mathrm{pH}$ of the soil, but the moisture content of the contaminated soils generally increased due to the growth of $S$. alata. There was a positive correlation $(\mathrm{p}=0.918)$ between the percentage remediation and the bioaccumulation factor, suggesting that the remediation of the heavy metals by the plant mostly occurred through bioaccumulation. A positive correlation between the percentage reduction of the heavy metals and the reduction of $\mathrm{pH}$ of the soil noticed suggests that growth of $S$. alata leads to decrease in soil $\mathrm{pH}$ and will enhance the remediation of soil contaminated with the heavy metals. The findings of this study show that apart from the medicinal values of $S$. alata, it can be useful in remediation of heavy metal polluted soils which occurs mostly through phytoextraction.
\end{abstract}

Keywords: bioaccumulation; contaminated soil; heavy metals; phytoremediation; Senna alata

\section{Introduction}

Senna alata is native to tropical South America (i.e. French Guiana, Guyana, Surinam, Venezuela, Brazil and Colombia). It is widespread species with a scattered distribution throughout northern and eastern Australia. It is most common in the coastal and sub-coastal parts of the Northern territory and northern Queensland but less common along the central and southern coasts of Queensland. It has also been recorded in north-western Western Australia. It has naturalised in tropical Africa, tropical Asia, Papua New Guinea, Mexico, south-eastern USA (i.e. Florida), the Caribbean and on several Pacific islands (i.e. the Cook Islands, 
Fiji, Guam, Palau, Tonga, Western Samoa and Hawaii). It grows rapidly in full sun on a wide range of soils (Gilman and Watson, 1993)

There are many medicinal and industrial uses of Senna alata. S. alata is used as a laxative or purgative and in the treatment of skin problems (Villasenor et al., 2000; Idu et al., 2007; Lewis and Levy, 2011). In addition, many species of Senna have been shown to have the ability to enhance the remediation of different heavy metals. Some of such include: Cassia tora (Ghose and Singh, 2005; Gupta and Sinha, 2008), C. multijuga (Siringoringo, 2000), C. siamen (Kumar et al., 2002; Raju et al., 2008; Jamhulkar and Juwarkar, 2009), C.fistula (Hanif et al., 2007) and C. italic (Al-Qahtani, 2012). However, little or no information in literature on the ability of $S$. alata to enhance the clean-up of heavy metals contaminated was available as at the time of this study. Establishing such will add to the economic value of the plant and increase the number of plants that can be used to remove heavy metals from contaminated soil

Heavy metal pollution poses serious problem to the ecosystem and the dependent organisms. According to Aluko et al. (2018), several studies have linked heavy metal accumulation to numerous several health diseases and abnormalities which include short- and long-time safety alongside environmental and health risk. Heavy metals toxicity induces different physiological interferences in different organisms in the ecosystem affecting their performance and survival. According to Sarma (2011), exposure to high levels of heavy metals has been linked to adverse effects on human health and wildlife. In plants, heavy metal toxicity can be manifested in form of reduced root length and shoot height and reduced yield. These can occur due to the interference of heavy metals with net photosynthetic rate and limitations in stomatal conductance which occur as a result of the disorganization of chloroplast structure by heavy metals like Cr (Santana et al., 2012)

The major sources of heavy metals contamination are geological and anthropogenic activities (Dembitsky, 2003). Industrial effluents, fuel production, mining, smelting processes, military operations, utilization of agricultural chemicals, small-scale industries, brick kilns and coal combustion are the major anthropogenic activities that serve as sources of heavy metals to the environment (Zhen-Guo et al., 2002). The major heavy metals found in contaminated sites are lead, chromium, arsenic, zinc, cadmium, copper, mercury, and nickel (GWARTAC, 1997). The total or the amount of heavy metals present in the soil is a function of the metal present in the parent material, atmospheric deposition, agrochemical sources, organic waste, inorganic pollutants, crop removal ability and losses due to leaching, volatilization etc. (Alloway, 1995; Lombi and Gerzabek, 1998). As heavy metals generally do not undergo degradation, their impacts persist for long in the environment (Adriano, 2003). Therefore, it is important to remove the heavy metals from the environment.

The different methods of heavy metal remediation are classified into four categories namely; isolation, immobilization, toxicity/mobility reduction and extraction (GWRTAC, 1997). As was noted by GWRTAC (1997), immobilization, soil washing and phytoremediation are techniques that are frequently listed among the Best Demonstrated Available Technologies (BDATs) for remediation of heavy metal contaminated sites. Phytoextraction, rhizoextraction and phytostabilization (immobilization) are the major processes for phytoremediation of heavy metals. Phytoremediation takes the advantage of the unique and selective uptake capabilities of plant root system together with the translocation, bioaccumulation and contaminant degradation abilities of the entire plant body (Hinchman et al., 1995)

In this study, the potential of Senna alata to remediate soils contaminated with heavy metals was investigated using artificially contaminated soil. It was based on the discovery of the environmental role of $S$. alata putting to consideration the well documented medicinal functions of the plant. Reports of Silva $e t$ al. (2014) showed that Cassia alata can be found in area used to disposal of waste and contaminated with heavy metals, mainly cadmium, copper, zinc, and lead. Review by Sarma (2011) showed list of some hyperaccumulating plants; however, $S$. alata was not included in such list. This suggests that little is known about the potential of $S$. alata as a hyperaccumulator of heavy metals. 


\section{Materials and Methods}

\section{Sources of materials}

\section{Experimental design}

The soil used for this study was obtained from the University of Lagos Botanical garden, Akoka Lagos, Nigeria. The soil was properly sieved to remove debris and stones. One kilogram of the sieved soil was used to fill each of the experimental pots $(20 \mathrm{~cm}$ wide and $10 \mathrm{~cm}$ high). A total of seventy-eight pots were used grouped into twelve groups of six pots each and each group was contaminated with a given amount of each heavy metal based on WHO limits (WHO, 1996) for heavy metals in plants. A group of three pots were not contaminated with any heavy metal and served as control for the growth study. Each group was divided into two subgroups (three pots each). One subgroup had no Senna alata which served as the control for the remediation study (Njoku et al., 2014) while each pot of the other subgroup was planted with ten seeds of S. alata.

\section{Contamination of soil and planting of seeds}

Each of the two groups of pots was experimentally contaminated with a given a quantity of a particular heavy metal. The levels of the heavy metals used were: lead $(150 \mathrm{mg} / \mathrm{kg}, 300 \mathrm{mg} / \mathrm{kg}$ and $450 \mathrm{mg} / \mathrm{kg})$, cadmium $(1.5 \mathrm{mg} / \mathrm{kg}, 3.0 \mathrm{mg} / \mathrm{kg}, 4.5 \mathrm{mg} / \mathrm{kg})$, nickel $(25 \mathrm{mg} / \mathrm{kg}, 50 \mathrm{mg} / \mathrm{kg}$ and $75 \mathrm{mg} / \mathrm{kg})$ and chromium $(50 \mathrm{mg} / \mathrm{kg}, 100$ $\mathrm{mg} / \mathrm{kg}$ and $150 \mathrm{mg} / \mathrm{kg}$ ). After contamination, the soils and the salts were thoroughly mixed with hand trowel to ensure uniform distribution of the metals. The pots were regularly watered with $100 \mathrm{mls}$ of water.

\section{Determination of the performance of $S$. alata in heavy metal contaminated soil}

The performance of the $S$. alata seedlings in heavy metal contaminated soils was determined by measuring the plant height, the leaf area (Francis et al., 1969) and number of actively growing branches.

\section{Collection and preparation of soil and plant samples}

The soil samples were collected from each of the experimental pot on the day of contamination (initial sample) and on 60 days after planting the seeds of $S$. alata (final sample). Plant samples were collected by carefully uprooting the plants from the experimental pots on day 60 . The soil and the plant samples were air dried. The soil samples were sieved while the plant samples were ground to fine powder.

\section{Determination of heavy metals levels in the soil and plant samples}

The heavy metals in the soil were extracted using the Potentials Bioavailable Sequential Extraction (PHASE) method as described by Basta and Gradwohl (2000) while the heavy metals in the plant samples were extracted using the wet ashing method as described by Tüzen (2003). The levels of heavy metals in the extracts were determined using the atomic absorption spectrophotometry method as was described in Aluko et al. (2018).

\section{Bioaccumulation factor and remediation potentials}

The bioaccumulation factor (BAF) of the plant tissues was calculated as a ratio of heavy metal level in the plant tissue to that in the soil using the formula of Ghosh and Singh (2005).

Bioaccumulation Factor $=\frac{\text { Heavy metal level in the plant tissue }}{\text { heavy metal level in the soil }}$

The ability of $S$. alata to remediate heavy metal contaminated soil (remediation potential) was calculated using the formula stated in Njoku et al. (2014) as follows

Remediation potential (\% reduction due to plant growth)

$=\frac{\text { Amount of heavy metal lost due to growth of S.alata }}{\text { final heavy metal level in the soil in soil without plant }} \times 100$ 
Amount of heavy metal lost due to growth of $S$. alata = final amount of heavy metal is soil without $S$. alata - final amount of heavy metal in soil with $S$. alata.

\section{Effect of the growth of S. alata on the physico-chemical characteristics of the contaminated soil}

The effect of growth of $S$. alata on the $\mathrm{pH}$ and the cation exchange capacity of the heavy metal contaminated soil were determined as described by Ugwu (2015). The moisture content and the total organic matter contents of the soils were determined as described by O'Kelly (2004) and Azlan et al. (2012) respectively. The impact of the growth of the plant on each parameter was determined by subtracting the final value in the soil with the plant from the final value in soil without plant and using that as a percentage of the final level of the parameter in soil without the plant.

\section{Statistical analyses}

Data obtained were statistically analysed using the GraphPad Prism software 7.0 version. Means were compared at 95\%, 99\% and 99.9\% levels of significance. Data were correlated to determine their levels of association and relatedness.

\section{Results}

\section{The performance of Senna alata in heavy metal contaminated soil}

The leaf area, plant height and number of actively growing branches of $S$. alata grown in heavy metal contaminated soils are shown in Table 1 . The leaf area, the plant height and the number of actively growing stems generally decreased with increase in the amount of each metal added to the soil. Plants in lead contaminated soil had best growth performance while the performance of the plant was generally worst in cadmium contaminated soil. The values of the growth parameters varied according to the metals. The leaf area of the plant in soil treated with $450 \mathrm{mg}$ lead and $75 \mathrm{mg}$ nickel were significantly lower $(\mathrm{p}<0.05)$ than the leaf area of the plant in the soil without the heavy metal. The leaf area has positive correlation of $\mathrm{r}=0.909 \mathrm{and} \mathrm{r}=$ 0.845 with the shoot height and the number of branches respectively. Cadmium had greatest effect on leaf area and number of actively growing branches ( $41.67 \%$ reduction and $80.34 \%$ reduction respectively) which the greatest effect on the plant height was produced by nickel ( $71.70 \%$ reduction). For all the growth parameters measured, the effects of nickel and cadmium treatment were least on the leaf area and greatest on the number of actively growing branches. For lead treatment, the least effect was on the actively growing branches $(31.62 \%)$ and the greatest effect was on the plant height (45.28\%) and in the case of chromium treatment, the effect was least on the leaf area $(36.67 \%)$ and greatest on the number of the actively growing branches $(68.38 \%)$.

\section{Heavy metal content of the soil and the percentage loss for each heavy metal}

The amount of each of the heavy metals in the soil at the end of the study and the percentage loss for each heavy metal is shown in Table 2 . The amount of each heavy metal in the soil reduced at the end of the study (60 days). Further reduction of the amount of each heavy metal was observed in soils with $S$. alata compared to soils without the plant at the end of 60 days. The highest reduction of the metals due to the growth of $S$. alata occurred in soil with $3.0 \mathrm{mg} / \mathrm{kg}$ of Cd (82.83\%). The least reduction was observed in soil treated with $50 \mathrm{mg} / \mathrm{kg}$ of $\mathrm{Ni}(18.60 \%$ reduction). There was significant reduction $(\mathrm{P}<0.05)$ of the heavy metals due to the growth of $S$. alata compared to that in soil without plant. 
Table 1. The leaf area, plant height and number of actively growing branches of $S$. alata grown in heavy metal contaminated soils

\begin{tabular}{|c|c|c|c|c|}
\hline Heavy metal & $\begin{array}{l}\text { Amount added to the soil } \\
\qquad(\mathrm{mg} / \mathrm{kg})\end{array}$ & $\begin{array}{l}\text { Leaf area } \\
\left(\mathrm{cm}^{2}\right)\end{array}$ & $\begin{array}{l}\text { Plant height } \\
(\mathrm{cm})\end{array}$ & $\begin{array}{l}\text { Number of actively } \\
\text { growing branches }\end{array}$ \\
\hline \multirow{5}{*}{ Lead } & 0 & $3.00 \pm 0.622$ & $15.90 \pm 0.361$ & $11.70 \pm 1.528$ \\
\hline & 150 & $2.40 \pm 0.403$ & $9.80 \pm 2.646$ & $9.70 \pm 1.528$ \\
\hline & 300 & No Growth & No Growth & No Growth \\
\hline & 450 & $2.03 \pm 0.212$ & $8.70 \pm 0.345$ & $8.00 \pm 2.00$ \\
\hline & $\%$ Effect (reduction) & $32.33 \%$ & $45.28 \%$ & $31.62 \%$ \\
\hline \multirow{5}{*}{ Chromium } & 0 & $3.00 \pm 0.622$ & $15.90 \pm 0.361$ & $11.70 \pm 1.528$ \\
\hline & 50 & $2.20 \pm 0.191$ & $10.00 \pm 0.808$ & $5.30 \pm 1.115$ \\
\hline & 100 & $2.00 \pm 0.064$ & $6.40 \pm 0.351$ & $3.70 \pm 1.528$ \\
\hline & 150 & $1.90 \pm 0.071$ & $6.00 \pm 0.200$ & $3.70 \pm 2.002$ \\
\hline & \% Effect (reduction) & $36.67 \%$ & $62.26 \%$ & $68.38 \%$ \\
\hline \multirow{5}{*}{ Nickel } & 0 & $3.00 \pm 0.622$ & $15.90 \pm 0.361$ & $11.70 \pm 1.528$ \\
\hline & 25 & $2.28 \pm 0.064$ & $9.20 \pm 0.723$ & $4.30 \pm 1.528$ \\
\hline & 50 & $2.20 \pm 0.509$ & $5.40 \pm 0.200$ & $3.70 \pm 1.115$ \\
\hline & 75 & $1.80 \pm 0.177$ & $4.50 \pm 0.153$ & $3.00 \pm 1.000$ \\
\hline & \% Effect (reduction) & $40.00 \%$ & $71.70 \%$ & $74.36 \%$ \\
\hline \multirow{5}{*}{ Cadmium } & 0 & $3.00 \pm 0.622$ & $15.90 \pm 0.361$ & $11.70 \pm 1.528$ \\
\hline & 1.5 & $2.20 \pm 0.504$ & $8.20 \pm 0.667$ & $4.30 \pm 1.528$ \\
\hline & 3.0 & $1.80 \pm 0.177$ & $5.10 \pm 0.115$ & $4.30 \pm 2.517$ \\
\hline & 4.5 & $1.75 \pm 0.212$ & $5.50 \pm 0.208$ & $2.30 \pm 0.577$ \\
\hline & \% Effect (reduction) & $41.67 \%$ & $65.41 \%$ & $80.34 \%$ \\
\hline
\end{tabular}

Values $=$ mean \pm standard error of mean

Table 2. Heavy metal level $(\mathrm{mg} / \mathrm{kg})$ in soils before and after remediation with S. alata.

\begin{tabular}{|c|c|c|c|c|c|}
\hline \multirow{3}{*}{ Heavy metal } & $\begin{array}{c}\text { Amount } \\
\text { added to the } \\
\text { soil }(\mathrm{mg} / \mathrm{kg})\end{array}$ & $\begin{array}{c}\text { Initial } \\
\text { level }\end{array}$ & $\begin{array}{c}\text { Final level in soil } \\
\text { without plant }\end{array}$ & $\begin{array}{c}\text { Final level in soil } \\
\text { with plant }\end{array}$ & $\begin{array}{c}\text { Percentage } \\
\text { reduction due to } \\
\text { plant growth }\end{array}$ \\
\hline \multirow{4}{*}{ Lead } & 150 & $147.90 \pm 0.005$ & $117.67 \pm 0.005$ & $84.05 \pm 0.005$ & 28.57 \\
\cline { 2 - 6 } & 300 & $295.40 \pm 0.003$ & $168.80 \pm 0.004$ & No Growth & Not Applicable \\
\cline { 2 - 6 } & 450 & $446.92 \pm 0.006$ & $207.87 \pm 0.004$ & $165.52 \pm 0.006$ & 20.37 \\
\hline \multirow{3}{*}{ Chromium } & 50 & $46.50 \pm 0.002$ & $37.20 \pm 0.003$ & $26.37 \pm 0.003$ & 21.05 \\
\cline { 2 - 6 } & 100 & $97.09 \pm 0.003$ & $55.47 \pm 0.004$ & $45.16 \pm 0.004$ & 18.59 \\
\hline & 150 & $148.02 \pm 0.004$ & $68.85 \pm 0.004$ & $53.02 \pm 0.004$ & 22.99 \\
\cline { 2 - 6 } & 25 & $24.00 \pm 0.003$ & $19.20 \pm 0.002$ & $13.72 \pm 0.003$ & 28.54 \\
\hline \multirow{3}{*}{ Cadmium } & 75 & $48.94 \pm 0.004$ & $27.97 \pm 0.003$ & $22.77 \pm 0.002$ & 18.60 \\
\cline { 2 - 6 } & 3.5 & $76.88 \pm 0.003$ & $35.76 \pm 0.002$ & $27.77 \pm 0.003$ & 22.36 \\
\cline { 2 - 6 } & 4.5 & $1.01 \pm 0.001$ & $0.81 \pm 0.000$ & $0.58 \pm 0.000$ & 28.55 \\
\hline
\end{tabular}

Values are mean \pm standard error of mean of three replicates. NG $=$ No growth; NA $=$ Not Applicable

\section{Bioaccumulation of heavy metals in the plant tissues}

The amount of lead and chromium metals accumulated in the plant tissues increased with increase in the amount of heavy metal added to the soil (Table 3). In the case of nickel, the level of accumulation decreased with increase in the amount of the metal added to the soil. Accumulation of cadmium in the soil was highest 
in the soil treated with $3.0 \mathrm{mg}$ of cadmium. The highest bioaccumulation factor (9.47) was observed in the plant that grew in the soil treated $3.0 \mathrm{mg}$ of cadmium. This was followed by the plant that grew in the soil treated with $3.0 \mathrm{mg}$ of cadmium. The least bioaccumulation factor was recorded in plant that grew in soil 75 mg of nickel (0.04) on the average, the plant that grew in lead contaminated soil had the least bioaccumulation factor while the plants that grew in the cadmium contaminated soil had the highest average bioaccumulation factor. The trend of bioaccumulation factor recorded is similar to that of the accumulation of the heavy metals in the plant tissues.

Table 3. Heavy metal level in plants tissues and their bioaccumulation factor

\begin{tabular}{|c|c|c|c|c|}
\hline Heavy metal & $\begin{array}{c}\text { Amount added } \\
\text { to the soil }\end{array}$ & $\begin{array}{c}\text { Final level in soil } \\
\text { with plant }\end{array}$ & $\begin{array}{c}\text { Amount in the } \\
\text { plant tissue }\end{array}$ & $\begin{array}{c}\text { Bioaccumulation } \\
\text { factor (BAF) }\end{array}$ \\
\hline \multirow{3}{*}{ Lead } & 150 & $84.05 \pm 0.005$ & $12.15 \pm 0.000$ & 0.14 \\
\cline { 2 - 5 } & 300 & No Growth & Not Applicable & Not Applicable \\
\cline { 2 - 5 } & 450 & $165.52 \pm 0.006$ & $25.75 \pm 0.000$ & 0.16 \\
\hline \multirow{3}{*}{ Chromium } & 50 & $26.37 \pm 0.003$ & $6.56 \pm 0.003$ & 0.25 \\
\cline { 2 - 5 } & 100 & $45.16 \pm 0.004$ & $8.20 \pm 0.004$ & 0.18 \\
\hline \multirow{3}{*}{ Nickel } & 150 & $53.02 \pm 0.004$ & $11.00 \pm 0.003$ & 0.21 \\
\cline { 2 - 5 } & 25 & $13.72 \pm 0.003$ & $4.79 \pm 0.002$ & 0.35 \\
\hline \multirow{3}{*}{ Cadmium } & 50 & $22.77 \pm 0.002$ & $3.32 \pm 0.003$ & 0.15 \\
\cline { 2 - 5 } & 75 & $27.77 \pm 0.003$ & $1.03 \pm 0.000$ & 0.04 \\
\cline { 2 - 5 } & 1.5 & $0.58 \pm 0.000$ & $1.87 \pm 0.004$ & 3.24 \\
\hline
\end{tabular}

\section{The effect of Senna alata growth on the $p H$ of heavy metal contaminated soils}

The $\mathrm{pH}$ of the heavy metal contaminated soil at the beginning and the end of the study is shown in Table 4. The $\mathrm{pH}$ of the soil generally dropped with the addition of the heavy metals. Addition of $\mathrm{Pb}$ led to the highest drop of the $\mathrm{pH}$ of soil while the addition of $\mathrm{Cd}$ led to the least drop of the soil $\mathrm{pH}$. The $\mathrm{pH}$ of the soil dropped generally at the end of 60 days compared to the initial $\mathrm{pH}$. The growth of $S$. alata contributed to further drop of the $\mathrm{pH}$ of the soil in all the treatments. The highest drop of the soil $\mathrm{pH}$ due to the growth of $S$. alata occurred in soil with $25 \mathrm{mg} \mathrm{Ni}(8.02 \%)$. The drop of soil $\mathrm{pH}$ due to the growth of $S$. alata was least in the soil with $1.5 \mathrm{mg}$ of $\mathrm{Cd}(5.14 \%)$. The $\mathrm{pH}$ of soil with $S$. alata significantly dropped $(\mathrm{P}<0.05)$ compared to the initial $\mathrm{pH}$.

Table 4. $\mathrm{pH}$ of soils before and after remediation of heavy metals with S. alata

\begin{tabular}{|c|c|c|c|c|c|}
\hline Heavy metal & $\begin{array}{c}\text { Amount added } \\
\text { to the soil }(\mathrm{mg})\end{array}$ & $\begin{array}{c}\text { Initial } \\
\mathrm{pH}\end{array}$ & $\begin{array}{c}\text { Final pH in soil } \\
\text { without plant }\end{array}$ & $\begin{array}{c}\text { Final pH in soil } \\
\text { with plant }\end{array}$ & $\begin{array}{c}\text { Percentage reduction } \\
\text { due to plant growth }\end{array}$ \\
\hline \multirow{4}{*}{ Lead } & 150 & 7.21 & 6.89 & 6.53 & 5.22 \\
\cline { 2 - 6 } & 300 & 7.08 & 6.62 & No growth & Not Applicable \\
\cline { 2 - 6 } & 450 & 6.89 & 6.57 & 6.21 & 5.48 \\
\hline \multirow{3}{*}{ Chromium } & 50 & 7.29 & 6.97 & 6.61 & 5.16 \\
\cline { 2 - 6 } & 100 & 7.15 & 6.88 & 6.47 & 6.09 \\
\cline { 2 - 6 } & 150 & 7.105 & 6.73 & 6.32 & 8.02 \\
\hline \multirow{3}{*}{ Cadmickel } & 25 & 7.30 & 6.98 & 6.42 & 5.26 \\
\cline { 2 - 6 } & 50 & 7.17 & 6.85 & 6.49 & 5.32 \\
\cline { 2 - 6 } & 75 & 7.09 & 6.77 & 6.41 & 5.22 \\
\cline { 2 - 6 } & 1.5 & 7.32 & 7.00 & 6.53 & 5.31 \\
\hline
\end{tabular}




\section{The effect of Senna alata growth on the total organic matter content of heavy metal contaminated soils}

The organic matter content of heavy metal contaminated soil before and after remediation of heavy metals with $S$. alata is shown in Table 5. The organic matter content of the soils reduced with the addition of heavy metals. There was also reduction of the organic matter content of the soil at the end of 60 days. Growth of $S$. alata led to further reduction of the organic matter content of the soil. The highest reduction of the total organic matter content of the soil due to the growth of $S$. alata (51.65\%) was observed in the soil with $50 \mathrm{mg}$ of Cr of treatment. The least reduction of the total organic matter content of the soil due to the growth of $S$. alata was observed in soil with $4.5 \mathrm{mg}$ of $\mathrm{Cd}(10.29 \%)$. The organic matter content of the soil on day 60 in soil with $100 \mathrm{mg} / \mathrm{kg}$ chromium was significantly lower than the initial organic matter content $(\mathrm{p}<0.05)$.

Table 5. Organic matter content of soil before and after remediation of heavy metals with S. alata

\begin{tabular}{|c|c|c|c|c|c|}
\hline \multirow{2}{*}{ Heavy metal } & $\begin{array}{c}\text { Amount added } \\
\text { to the soil }\end{array}$ & $\begin{array}{c}\text { Initial } \\
\text { level }\end{array}$ & $\begin{array}{c}\text { Final level in soil } \\
\text { without plant }\end{array}$ & $\begin{array}{c}\text { Final level in soil } \\
\text { with plant }\end{array}$ & $\begin{array}{c}\text { Percentage reduction due } \\
\text { to plant growth }\end{array}$ \\
\hline \multirow{3}{*}{ Lead } & 150 & 77.90 & 58.05 & 49.40 & 14.90 \\
\cline { 2 - 6 } & 300 & 77.32 & 56.45 & No Growth & Not Applicable \\
\cline { 2 - 6 } Chromium & 450 & 77.00 & 56.45 & 44.57 & 21.05 \\
\cline { 2 - 6 } & 50 & 78.12 & 58.39 & 50.81 & 12.98 \\
\cline { 2 - 6 } & 100 & 75.12 & 57.27 & 27.69 & 18.83 \\
\hline \multirow{3}{*}{ Nickel } & 25 & 73.03 & 56.18 & 45.60 & 16.22 \\
\cline { 2 - 6 } & 50 & 78.46 & 59.07 & 49.49 & 16.63 \\
\hline \multirow{3}{*}{ Cadmium } & 75 & 78.21 & 57.61 & 48.03 & 15.15 \\
\cline { 2 - 6 } & 1.5 & 79.02 & 72.38 & 71.99 & 13.54 \\
\cline { 2 - 6 } & 3.0 & 78.45 & 55.66 & 50.41 & 11.93 \\
\hline
\end{tabular}

\section{The effect of Senna alata growth on the moisture content of heavy metal contaminated soils}

Table 6 shows the moisture content of heavy metal contaminated soil before and after remediation of heavy metals with $S$. alata. The moisture content increased generally with the addition of the heavy metals. Addition of lead to the soil led to the highest increase in the moisture content. The initial moisture content increased generally with the increase in the amount of the metals added to the soil. For soil without heavy metals, there was $0.78 \%$ reduction of the moisture content due to the growth of $S$. alata. For the contaminated soils, the moisture content of the soil at the end of 60 days dropped in soils without plant. However, the moisture content of soil due to growth of $S$. alata generally increased. The percentage increase of the moisture content of the soil due to the growth of $S$. alata generally decreased as the amount of heavy metal added to the soil increased.

\section{The effect of Senna alata growth on the cation exchange capacity of heavy metal contaminated soils}

The effect of Senna alata growth on the cation exchange capacity of heavy metal contaminated soils is shown in Table 7. The cation exchange capacity of the soil generally increased with the addition of the heavy metals into the soil. There was reduction of the cation exchange capacity at the end of 60 days. This was further reduced due to the growth of $S$. alata. The reduction of the cation exchange capacity was highest in soil without any metal (46.51\%). In the soils treated with the different heavy metals, the reduction of the cation exchange capacity due to the growth $S$. alata generally increased with the amount of heavy metal added into the soil. However, for the soil treated with cadmium, the percentage reduction of cation exchange capacity due to the growth of $S$. alata decreased with increase in amount of the metal added into the soil. 
Njoku KL et al. (2020). Not Sci Biol 12(2):420-432.

Table 6. Moisture content of soil before and after remediation of heavy metals with $S$. alata

\begin{tabular}{|c|c|c|c|c|c|}
\hline Heavy metal & $\begin{array}{c}\text { Amount added to } \\
\text { the soil }\end{array}$ & $\begin{array}{c}\text { Initial } \\
\text { level }\end{array}$ & $\begin{array}{c}\text { Final level in soil } \\
\text { without plant }\end{array}$ & $\begin{array}{c}\text { Final level in soil } \\
\text { with plant }\end{array}$ & $\begin{array}{c}\text { Percentage change } \\
\text { due to plant growth }\end{array}$ \\
\hline \multirow{3}{*}{ Lead } & 150 & 8.31 & 6.15 & 14.00 & 127.64 \\
\cline { 2 - 6 } & 300 & 9.20 & 6.63 & No growth & Not Applicable \\
\cline { 2 - 6 } & 450 & 10.63 & 7.63 & 13.08 & 71.43 \\
\hline \multirow{3}{*}{ Chromium } & 50 & 8.58 & 5.45 & 18.45 & 238.53 \\
\cline { 2 - 6 } & 100 & 8.58 & 6.00 & 15.88 & 164.67 \\
\hline \multirow{3}{*}{ Nickel } & 150 & 9.73 & 6.55 & 16.09 & 145.65 \\
\cline { 2 - 6 } & 25 & 7.76 & 5.18 & 18.05 & 148.46 \\
\hline \multirow{3}{*}{ Cadmium } & 50 & 8.03 & 5.45 & 13.10 & 129.32 \\
\cline { 2 - 6 } & 15 & 8.31 & 5.73 & 17.15 & 229.00 \\
\cline { 2 - 6 } & 3.0 & 8.08 & 5.20 & 14.25 & 159.09 \\
\hline
\end{tabular}

Table 7. Cation exchange capacity of soil before and after remediation of heavy metals with $S$. alata

\begin{tabular}{|c|c|c|c|c|c|}
\hline \multirow{3}{*}{ Heavy metal } & $\begin{array}{c}\text { Amount added } \\
\text { to the soil }\end{array}$ & Initial level & $\begin{array}{c}\text { Final level in soil } \\
\text { without plant }\end{array}$ & $\begin{array}{c}\text { Final level in soil } \\
\text { with plant }\end{array}$ & $\begin{array}{c}\text { Percentage } \\
\text { reduction due to } \\
\text { plant growth }\end{array}$ \\
\hline \multirow{3}{*}{ Lead } & 150 & 30.58 & 18.62 & 15.15 & 18.64 \\
\cline { 2 - 6 } & 300 & 32.56 & 17.22 & No Growth & No Growth \\
\cline { 2 - 6 } Chromium & 450 & 35.48 & 15.99 & 12.50 & 21.84 \\
\cline { 2 - 6 } & 100 & 28.84 & 15.84 & 12.55 & 20.77 \\
\hline \multirow{3}{*}{ Nickel } & 150 & 31.49 & 14.23 & 11.08 & 22.14 \\
\cline { 2 - 6 } & 25 & 22.43 & 13.71 & 10.48 & 23.56 \\
\cline { 2 - 6 } & 50 & 24.39 & 11.49 & 8.98 & 28.64 \\
\hline \multirow{3}{*}{ Cadmium } & 75 & 26.93 & 9.34 & 6.89 & 26.23 \\
\cline { 2 - 6 } & 1.5 & 23.30 & 13.31 & 10.83 & 18.63 \\
\cline { 2 - 6 } & 3.0 & 25.88 & 12.05 & 10.08 & 16.34 \\
\hline
\end{tabular}

The correlation analysis of the different soil parameters is shown in Table 8. The percentage remediation of the heavy metals had a high positive correlation with the bioaccumulation factor $(r=0.918)$ and No correlation $\approx 0$ with the soil moisture change $(\mathrm{r}=-0.035)$. The total organic matter reduction of the soil also has a negative correlation $(\mathrm{r}=-0.165)$ with the bioaccumulation factor. The bioaccumulation factor also had a negative correlation $(\mathrm{r}=-0.158)$ with the cation exchange capacity of the soil. The highest correlation of the $\mathrm{pH}$ was with the soil cation exchange capacity $(\mathrm{r}=0.810)$ while no correlation of the $\mathrm{pH}$ was with the bioaccumulation factor $(\mathrm{r}=0.032)$. The correlation of the organic matter content of the soil was with $\mathrm{pH}(\mathrm{r}$ $=0.731)$ while the least correlation was with bioaccumulation $(r=0.172)$ 
Table 8. Pearson correlation coefficient of percentage remediation, $\mathrm{pH}$, TOM, Moisture content, bioaccumulation factor and cation exchange capacity

\begin{tabular}{|c|c|c|c|c|c|c|}
\hline & $\begin{array}{c}\% \\
\text { Remediation }\end{array}$ & BAF & $\begin{array}{c}\mathrm{pH} \\
\text { reduction }\end{array}$ & $\begin{array}{c}\text { Moisture } \\
\text { change }\end{array}$ & $\begin{array}{c}\text { Organic matter } \\
\text { reduction }\end{array}$ & $\begin{array}{c}\text { Reduction in } \\
\text { CEC }\end{array}$ \\
\hline \% Remediation & 1 & & & & & \\
\hline BAF & 0.918 & 1 & & & & \\
\hline $\mathrm{pH}$ reduction & 0.341 & 0.032 & 1 & & & \\
\hline Moisture change & -0.035 & -0.165 & 0.471 & 1 & & \\
\hline $\begin{array}{c}\text { Organic matter } \\
\text { reduction }\end{array}$ & 0.310 & 0.172 & 0.731 & 0.187 & 1 & 1 \\
\hline Reduction in CEC & 0.114 & -0.158 & 0.810 & 0.439 & 0.523 & \\
\hline
\end{tabular}

\section{Discussion}

The choice of a plant for phytoremediation of heavy metal contaminated medium depends on some factors like the level of tolerance of the proposed plant to the pollutant in question and the ability of the plant to uptake, accumulate and translocate the heavy metal (Sarma, 2011). The ability of an organism to survive the conditions in a contaminated medium is a major factor to be considered when choosing an organism for bioremediation studies, thus the ability of $S$. alata to survive in the heavy metal contaminated soils used in this study suggests that its ability to remediate heavy metal contaminated soils in the field can be validated. The results we obtained in this study generally indicate that the growth of $S$. alata is negatively affected by the increase in the level of each of the metals in the soil but there was reduction in heavy metals levels in soils due to the growth of $S$. alata. Significant reduction of the heavy metals due to the growth of $S$. alata being reported in this study points to the fact that the plant can be used to reclaim soils contaminated with heavy metals especially cadmium. This thus shows that apart from the well reported medicinal values of the plant (Villasenor et al., 2000; Idu et al., 2007; Lewis and Levy, 2011), it has good environmental values as it is the case of the other species of Senna.

The bioavailability of heavy metals and their uptake by plants depend on several factors. In phytoremediation of heavy metals, the factors that affect heavy metals bioavailability and uptake play crucial roles. The results of the correlation analysis which were obtained in this study suggest that remediation of the heavy metals by $S$. alata may be much slightly inhibited by high moisture content of the soil and may be highly favoured by high bioaccumulation ability of the plant. This is in agreement with the work of Angle et al. (2003) which shows that in general, extractable soil concentrations of $\mathrm{Ni}$ and $\mathrm{Zn}$ decrease with increasing soil moisture content. According to Rieuwerts et al. (1998) most metals including $\mathrm{Zn}, \mathrm{Cd}$, and $\mathrm{Ni}$ in waterlogged soils exhibit complicated solubility with generally reduced solubility due to low redox potential and formation of sparingly soluble sulfides (Marschner, 1995).

The positive correlation between heavy metal remediation and the reduction of the organic matter content we reported so far in this study could be ascribed to the views of Suave et al. (2000) who had pointed out that solid phase soil organic matter inhibits bioavailability and mobility of metals in the soils. Thus, as the organic matter content reduces, the heavy metals become more bioavailable and more mobile thereby increasing ability of plants to absorb them. Also, Angelova et al. (2010) showed that amending soil with different organic soil additives increased the immobility of heavy metals $(\mathrm{Zn}, \mathrm{Pb}, \mathrm{Cd}$ and $\mathrm{Cu})$ and reduced their phyto accessibility and accumulation by potato. This could be due to the adsorption of the heavy metals by organic matter as was suggested by Kabata Pendias (2001). Similarly, the works of Silva et al. (2014) showed that organic matter content of soil have negative correlation with the available iron, lead, cadmium, copper and zinc in the soil. The availability of the metals is a major factor that affects the uptake and remediation by plants. The organic matter is one of the factors that may reduce the ability of metals to be phytotoxic in the soil due to 
metal-organic complexation. Notwithstanding the reduced absorption of heavy metals by plants which the presence of organic matter in the soil causes, augmenting the soil contaminated with heavy metals with organic matter can positively influence the remediation of the soil plant as the plants will have less toxic effect and can grow and secrete enzymes and proteins that will enhance the chelation of the heavy metals and their subsequent removal from soil. In fact, soils with low organic matter content have low biological activities and such activities are the basis of biological remediation. It should be of note that the phytoextraction of each heavy metal is optimum at different organic matter levels in the soils (Anh et al., 2010; Ha et al., 2018). Thus, in augmenting a heavy metal contaminated soil with organic matter to enhance phytoremediation, one needs to understand the optimum organic matter content for the heavy metal of interest. In addition, although high level of organic matter interferes with the bioavailability and phytoextraction of heavy metals, it helps in phyto stabilization of heavy metals which is another mechanism of phytoremediation of heavy metal contaminated soil. This shows that organic matter plays both active and passive roles in the cleaning or reducing the health risk associated with heavy metal contaminated soils

The reduction of the $\mathrm{pH}$ of the soil can slightly favour remediation of the heavy metals as they showed positive correlation with the percentage remediation. This is in consistent with reports of previous studies that heavy metals become more bioavailable at low $\mathrm{pH}$. The reports of McBride (1994), Blaylock and Huang (2000) and Prasad and Freitas (2003) have shown that reduction in soil pH reduces the adhesion of metals to soil particles thereby increasing their bioavailability and possible uptake by plants. This will increase the ability of plants to remove heavy metals from soil. Our results from this study also conform to such as the correlation between the percentage remediation and bioaccumulation of the heavy metals showed positive relationship with the reduction in the $\mathrm{pH}$ of the soil. These may suggest that reduced adhesion and increased bioavailability are positive factors that affect heavy metal bioaccumulation. Similar inference was made by Adamcyzk-Szabela et al. (2015) who stated that low $\mathrm{pH}$ prompts high metal mobility. The solubility of metals and the $\mathrm{pH}$ of soil are known to have inverse relation (Rieuwerts et al., 1998) implying that to achieve higher solubility of the heavy metals the $\mathrm{pH}$ should be low thus reduction of the $\mathrm{pH}$ of the soil due to the growth $S$. alata may be a mechanism that the plant uses to enhance the remediation of heavy metal polluted soil

The reduction in the cation exchange capacity as the plant grew showed a positive correlation with the $\mathrm{pH}$, the moisture, the organic matter content and the remediation of the heavy metals which suggests that the $\mathrm{CEC}$ influences these factors. It further suggests that to achieve good remediation results, it will be good to reduce the cation exchange capacity of the soil. This is consistent with the reports of Hinesly et al. (1982) which stated that cadmium uptake is inversely related with cation exchange capacity of a soil. The reduction of the cation exchange capacity observed in this study possibly occurred due to the interaction of the plant exudates released into the soil by $S$. alata with the soil properties. It is a known fact that the lower the CEC of a soil, the faster the $\mathrm{pH}$ will decrease and decrease in $\mathrm{pH}$ enhances the mobility and bioavailability of metals hence their uptake. Therefore, the reduction in CEC of the soil due the growth of $S$. alata as we have reported in this study could be one the reasons the $\mathrm{pH}$ of the soil dropped and hence making it possible for the plant to uptake the heavy metals.

Sarma (2011) noted that the uptake of metals largely depends on the type and chemical speciation of metal and habitat characteristics of plants. The difference in the ability of $S$. alata to bioaccumulate different heavy metals which we noticed in this study is similar to the observations of Jin et al. (2009) who reported that Sedum alfredii has higher bioaccumulation for $\mathrm{Zn}$ than $\mathrm{Cd}$ and Banasova and Horak (2008) who also showed that Thlaspi caerulescens had higher bioaccumulation for $\mathrm{Zn}$ than $\mathrm{Cd}$. These imply that no matter the level of efficiency of plant in enhancing the removal of heavy metals from the soil/environment, each plant can effectively lead to better removal of a particular heavy metal. This could be attributed to the can kind of exudate released by such plant the type of rhizospheric environment associated with the plant. The marginal high positive correlation $(p=0.918)$ between the percentage remediation and the bioaccumulation suggests that remediation of the heavy metals has a close association with their accumulation in the plant tissues. 


\section{Conclusions}

The results we obtained in this study showed that $S$. alata has the ability to facilitate the removal of different heavy metals from the soil. This study suggests that organic matter negatively influences the extent by which $S$. alata enhances the removal of heavy metals from the soil and bioaccumulation of the heavy metals in the plant tissues. Form the results; we can infer that although $S$. alata can contribute to the removal of the different heavy metals investigated in this study, it has greater influence on the removal of cadmium than the other heavy metals. Our results suggest that $S$. alata can be a good candidate for heavy metal remediation, but care should be taken in its suitability due its ability to bioaccumulate the heavy metals to avoid using it as a channel of transferring heavy metals to consumers in the food chain. This is essential as the plant has been documented to have many beneficial uses. The reduced performance as indicated by the indices we used in this plant shows that heavy metals also affect the growth of the plant.

\section{Conflict of Interests}

The authors declare that there are no conflicts of interest related to this article.

\section{References}

Adamczyk-Szabela D, Markiewicz J, Wolf WM (2015) Heavy metal uptake by herbs. IV. Influence of soil pH on the content of heavy metals in Valeriana officinalis L. Water Air Soil and Pollution 226(4):106.

Alloway BJ (1995). Heavy metals in soils. Blackie Academic and Professional, London, UK, 2nd edition.

Al-Qahtani KM (2012). Assessment of heavy metal accumulation in native plant species from soils contaminated in Riyadh city, Saudi Arabia. Life Science Journal 9:488-496.

Aluko TS, Njoku KL, Adesuyi AA, Akinola MO (2018). Health risk assessment of heavy metals in soil from the iron mines of Itakpe and Agbaja, Kogi State, Nigeria. Pollution 4(3):527-538.

Angelova V, Ivanova R, Pevicharova G, Ivanov K (2010). Effect of organic amendments on heavy metals uptake by potato plants. 19 $9^{\text {th }}$ World Congress of Soil Science, Soil Solutions for a Changing World 1 - 6 August 2010, Brisbane, Australia pp 84-87.

Angle JS, Baker AJM, Whiting SN, Chaney RL (2003). Soil moisture effects on uptake of metals by Thlaspi, Alyssum, and Berkheya. Plant and Soil 256:325-332.

Anh BK, Tua TV, Kim DD, Trang PTH (2010). Effect of N, P on growth and arsenic accumulation in fern Pteris vittata L. Journal of Science and Technology 48(2):71-78. (In Vietnamese).

Azlan A, Aweng ER, Ibrahim CO, Noorhaidah A (2012). Correlation between soil organic matter, total organic matter and water content with climate and depths of soil at different land use in Kelantan, Malaysia. Journal of Applied Science and Environmental Management 16(4): 353-359.

Banasova V, Horak O (2008). Heavy metal content in Thlaspi caerulescens J. et C. Presl growing on metalliferous and nonmetalliferous soils in Central Slovakia. International Journal of Environment and Pollution 33:133-145.

Basta N, Gradwohl R (2000). Estimation of $\mathrm{Cd}, \mathrm{Pb}$ and $\mathrm{Zn}$ bioavailability in smelter contaminated soils by a sequential extraction procedure. Journal of Soil contamination 9(2):149-164.

Blaylock MJ, Huang JW (2000). Phytoextraction of metals. In: Raskin I, Ensley BD (Eds). Phytoremediation of toxic metals: using plants to clean-up the environment. John Wiley \& Sons, Inc., New York pp 53-70.

Bolan NS, Adriano DC, Naidu R (2003). Role of phosphorus in (im) mobilization and bioavailability of heavy metals in the soil-plant system. In: Reviews of environmental contamination and toxicology. Springer, New York, NY pp 144.

Chu TT, Nguyen PH, Nguyen TH, Ha TV, Nguyen TT, Nguyen DA, Dang VA (2018). Effect of fertilizer on lead (Pb) accumulation ability of Polygonum hydropiper L. Journal of Vietnamese Environment 9(2):67-72. 
Dembitsky V (2003). Natural occurrence of arseno compounds in plants, lichens, fungi, algal species, and microorganisms. Plant Science 165:1177-1192.

Francis CA, Rutger JN, Palmer AFE (1969). A rapid method for plant leaf area estimation in maize (Zea mays L.). Crop Science 9:537-539.

Ghosh M, Singh SP (2005). A comparative study of cadmium phytoextraction by accumulator and weeds species. Environmental Pollution 133:365-371. http://dx.doi.org/10.1016/j.envpol.2004.05.015

Gilman EF, Watson DG (1993). Fact sheet ST-125 November 1993 Cassia alata. adapted from fact sheet ST-125, a series of the Environmental Horticulture Department, Florida Cooperative Extension Service, Institute of Food and Agricultural Sciences, University of Florida.

Gupta AK, Sinha S (2008). Decontamination and/or regeneration of fly ash dyke through naturally growing plant. Journal of Hazardous Materials 153:1078-1087.

GWRTAC (1997). Remediation of metals-contaminated soils and groundwater. Tech. Rep. TE-97-01, GWRTAC, Pittsburgh, Pa, USA, GWRTAC-E Series.

Hanif MA, Nadeem R, Bhatti H, Ahmed NR, Ansari TM (2007). Ni (II) biosorption by Cassia fistula (Golden Shower) biomass. Journal of Hazardous Materials 139(2):345-555.

Hinchman RR, Negri MC, Gatliff EG (1995). Phytoremediation: using green plants to clean up contaminated soil, groundwater, and wastewater. Argonne National Laboratory Hinchman, Applied Natural Sciences, Inc. http://www.treemediation.com/Technical/Phytoremediation_1998.pdf.

Hinesly TD, Redborg KE, Ziegler EL, Alexander JD (1982). Effect of soil cation exchange capacity on the uptake of cadmium by corn. Soil Science Society of America Journal 46(3):490-497.

Idu M, Omonigho SE, Igeleke CL (2007). Preliminary investigation on the phytochemistry and anti-microbial activity of Senna alata L. flower. Pakistan Journal of Biological Science 10:806-809.

Jambhulkar HP, Juwarkar AA (2009). Assessment of bioaccumulation of heavy metals by different plant species grown on fly ash dump. Ecotoxicity and Environmental Safety 72:1122-1128.

Jin X, Liu D, Islam E, Mahmood Q, Yang X, He Z, Stoffella P (2009). Effects of zinc on root morphology and antioxidant adaptations of cadmium- treated Sedum alfredii H. Journal of Plants Nutrition 32:1642-1656.

Kabata-Pendias A (2001). Trace elements in soils and plants. $3^{\text {rd }}$ Ed. CRC Press LLC, Boca Raton, Florida pp 403.

Kumar AP, Vajpayee P, Ali MB, Tripathi RD (2002). Biochemical response of Cassia siamea grown on coal combustion residue (fly ash). Bulletin of Environmental Contamination and Toxicology 68:675-683.

Lewis A, Levy A (2011). Anti-inflammatory activities of Cassia alata L. leaf extract in complete Freund's adjuvant arthritis in rats. West Indian Medicinal Journal 60(6):20-36.

Lombi E, Gerzabek MH (1998). Determination of mobile heavy metal fraction in soil: results of a pot experiment with sewage sludge. Communications in Soil Science and Plant Analysis 29(17-18):2545-2556.

Marschner H (1995). Mineral nutrition of higher plants. Academic Press Limited, London pp 889.

McBride MB (1994). Environmental chemistry of soils. Oxford University Press, ISBN 0-19-507011-9, New York pp 406.

Njoku KL, Akinola MO, Nkemdilim CM, Ibrahim PM, Olatunbosun AS (2014). Evaluation of the potentials of three grass plants to remediate crude oil polluted soil. Current Advances in Environmental Science 2(4):131-137.

O'Kelly BC (2004). Accurate determination of moisture content organic soils using the oven drying method. Drying Technology 22(7):1767-1776.

Prasad MNV, de Oliveira Freitas HM (2003). Metal hyperaccumulation in plants - biodiversity prospecting for phytoremediation technology. Electronic Journal of Biotechnology 6(3):285-321. http://dx.doi.org/10.4067/S0717-34582003000300012

Raju D, Sunil K, Mehta UJ, Hazra H (2008). Differential accumulation of manganese in three mature tree species (Holoptelia, Cassia and Neem) growing on a mine dump. Current Science 94:639-643.

Rieuwerts JS, Thornton I, Farago ME, Ashmore MR (1998). Factors influencing metal bioavailability in soil: preliminary investigations for the development of a critical loads approach for metals. Chemical Speciation and Bioavailability 10:61-75.

Santana KB, De Almeida AAF, Souza VL, Mangabeira PAO, Da Silva DC, Gomes FP, ... Loguercio LL (2012). Physiological analyses of Genipa americana L. reveals a tree with ability as phytostabilizer and rhizofilterer of chromium ions for phytoremediation of polluted watersheds. Environmental and Experimental Botany 80:35-42. 
Sarma H (2011). Metal hyperaccumulation in plants: a review focusing on phytoremediation technology. Journal of Environmental Science and Technology 4:118-138.

Silva JRR, Fernandes AR, Perez DV (2014). Phytoextraction of heavy metals from a landfill in the metropolitan region of Belém-Pará-Brazil. Amazonian Journal of Agricultural and Environmental Science 57:429-438. http://dx.doi.org/10.4322/rca.1525

Siringoringo $\mathrm{HH}$ (2000). The role of some urban forest plants in absorbing lead particulate. Bulletin of Penelitian-Hutan 622:1-16.

Tüzen M (2003). Determination of heavy metals in soil, mushroom and plant samples by atomic absorption spectrometry. Microchemical Journal 74(3):289-297.

Ugwu EC (2015). Hydrocarbon degradation and heavy metals uptake by Senna alata (L.) Roxb. in soil polluted with spent engine oil. A project report submitted in partial fulfilment of the requirement for the award of Master of Science [M.Sc.] in Environmental Plant Ecology, Department of Plant Science and Biotechnology, University of Nigeria, Nsukka, pp 90.

Villasenor IM, Canlas AP, Pascua MP, Sabando MN, Solien LA (2002). Bioactivity studies on Cassia alata L. leaf extract. Phytotherapy Resource 16(1):93-96.

World Health Organization (WHO) (1996). Permissible limits of heavy metals in soil and plants. Geneva, Switzerland.

Zhen-Guo S, Xian-Dong L, Chun-Chun W, Huai-Man H, Hong H (2002). Lead phytoextraction from contaminated soil with high biomass plant species. Journal of Environmental Quality 31:186-190.
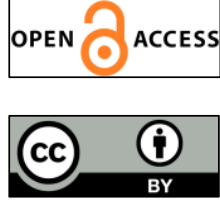

The journal offers free, immediate, and unrestricted access to peer-reviewed research and scholarly work. Users are allowed to read, download, copy, distribute, print, search, or link to the full texts of the articles, or use them for any other lawful purpose, without asking prior permission from the publisher or the author.

License - Articles published in Notulae Scientia Biologicae are Open-Access, distributed under the terms and conditions of the Creative Commons Attribution (CC BY 4.0) License.

(c) Articles by the authors; SHST, Cluj-Napoca, Romania. The journal allows the author(s) to hold the copyright/to retain publishing rights without restriction. 